\title{
CULTURAL AND HISTORICAL HERITAGE OF VELIKO TARNOVO FROM THE REVIVAL PERIOD IN THE HISTORICAL LITERATURE
}

\author{
(HISTORIOGRAPHIC ESSAY)
}

\author{
Pepa Valchanova \\ University of Veliko Tarnovo "St. st. Cyril and Metodius", Bulgaria \\ pepa.valchanova@abv.bg
}

\begin{abstract}
The recent report presents an attempt for study of the numerous research works and published results, which are in circulation throughout the scientific and research circles in relevance with the cultural and historical heritage of Veliko Tarnovo city from Revival period.

Following the already recognized periods in the development of historiography science, and also adding the last 20 years, part of the new 21 st century, the scopes and aims of the scientific research, whose object are different in their characteristics cultural and historical values, are classified and summarized. Veliko Tarnovo has a city territory, distinctive with its concentration of "memory" and eminent personalities. It has a leading role in the national movement for liberation, in the fights for clerical independence, marks a rapid development in economic and commercial sphere, presents a field for creative architectural decisions, and the most important - this is the place, where the Constituent assembly has been pursued, confirming the first Bulgarian Constitution. All these prerequisites lay onto the base of essence and functions of the heritage for setting identities and memory, for sustainable cultural and economic development, for future education and national selfdetermination.
\end{abstract}

Keywords: Cultural and Historical Heritage; Revival Period; City of Veliko Tarnovo; Historical Review; Periodization of Historiography Research; Memory; Sustainable Development

\section{ВЪЗРОЖАЕНСКОТО КУАТУРНО-ИСТОРИЧЕСКО НАСАЕАСТВО НА ВЕАИКО ТЪРНОВО В ИСТОРИЧЕСКАТА АИТЕРАТУРА (ИСТОРИОГРАФСКИ ОЧЕРК)}

\author{
Пепа Вьлчанова \\ Великотьрновски университет „Св. Св. Кирил и Методий“, България
}

Резюме: Настоящата статия представлява опит за проучване на многообразните изследвания и публикувани резултати, които са в обрьщение в научно-изследователските среди по отношение на възрожАенското културно-историческо наследство на граА Велико Търново. Следвайки утвърАените периоди в развитието на 
историографрията, но и с Аобавяне на послеАните 20 години, част от новия 21 век, се класифицират и обобщават насоките и целите на научните търсения, чиито обект са различни по своите характеристики културно-исторически ценности. Велико Търново притежава гралска територия, която се отличава с висока концентрация на „памет" и мичности с бележит характер. ГраАьт има водеща роля в национално-освободителното Авижение, в борбите за цьрковната ни независимост, отбелязва бурно развитие в стопанско-тьрговско отношение, предоставя поле за творчески архитектурни решения, и най-важното - тук е мястото, кьАето се провежла Учрелителното събрание, утвърлило първата българска конституция. Всички тези преАпоставки стоят в основата на същността и функциите на наследството за фрормирането на илентичности и памет, за устойчиво културно и икономическо развитие, за бълещото образование и национално самоопределяне.

КАючови Ауми: Културно-историческо наслеАство, Възраждане, Велико Търново, историографски очерк, периодизация на историографрските изслеАвания, памет, устойчиво развитие

Периольт на българското Възраждане, макар и настьпи^ в еАин Аоста по-късен момент в сравнение със запално-европейските общества по реА причини и обстоятелства, породени в най-голяма степен от османското завоевание в българските земи, е време на себеутвържАаването ни като нация и като отАелни Аичности, на съгражлане и Аьржавно устройство, на елиномислие в посока развитие на просвета, култура, градоустройство, стопанство, общество.

В историческата митература огромен е приносът на учените, които разглежАат процесите, започнали още в началото на XVIII век и продьлжаващи през целия XIX век, дори и в слеАосвобожленско време, от различна позиция и с различен фокус - Аали от глеАна точка на архитектурни решения, или по отношение на книжнината, която започва „Своя печат" и офрициално разпространение, с акцент върху просветното Аело или цьрковно-националните борби за освобожАение, върху отАелни ярко изявени мичности или общности, обединени от конкретна кауза. Цялата палитра от теми, обект на научни търсения и разработки, Аава възможност за по-пьлна реконструкция на събитията, процесите и тенденциите в този динамичен и твьрде важен за националното ни самочувствие периол. 
Културно-историческото наслеАство от Възраждането се отличава с особено разнообразие и многопосочност, като в своето развитие отАелните гралски центрове и поселения също отбелязват специфрики и ^окални особености.

В еАин чисто терминологичен аспект и обхват е необходимо тук $\Delta$ a ce посочи каква е утвърАената Аефриниция в послеАно постановения Закон за културното наслеАство, а именно „Културното наслеАство обхваща нематериалното и материалното неАвижимо и Авижимо наслеАство като съвкупност от културни ценности, които са носители на историческа памет, национална идентичност и имат научна и^и културна стойност"'.

Българският народ, който ревностно пази своите траАиции и ги предава в поколения, неизменно обръща своя „поглеА към Търново последната българска столица - с належАата, че нейното освобожление би означавало освобожАение и независимост на всички български земи. През епохата на Възраждането Търново се явява символ на българската Аьржавност, на българската свобола" (Pletnyov, 1985: р. 142).

Велико Търново - име, утвьрАено окончателно през 1965 г. с указ № 501, обнародван на 27 юли 1965 г., а Аотогава (от ОсвобожАението Ао 1965 г.) с промени на няколко пьти от Тьрново на Велико Търново и обратно (Beykova, Sabeva et al., 2013: 5) има волеща роля в националноосвободителното Авижение, в борбите за цьрковната ни независимост, отбелязва бурно развитие в стопанско-търговско отношение, предоставя поле за творчески архитектурни решения, но най-важното - тук е мястото, кълето се провежла Учредителното сьбрание, утвьрдило пьрвата българска конституция - еАна от най-Аемократичните за своето време, с което България се връща отново като Аьржавно фрормирование на картата на Европа. Многобройни са пьтеписите от български и чужАи пьтешественици, книгите, студиите, монографиите, статиите, мемоарите, публикациите,

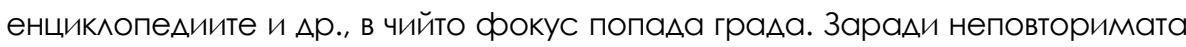
си и оригинална красота, характерна по своята специфика и Аетайли архитектура и лобро ниво на благоустрояване възрожленско Търново би^ наричан от своите съвременници Мальк ЦариграА.

${ }^{1}$ Закон за културното наследство 2009 г., ч^. 2, ал. 1 (Cultural Heritage Act 2009 [https://www.lex.bg/laws/ldoc/2135623662, (Last view: 15.06.2020)]. 
И все пак, Аори при наличието на толкова разнообразна научна и популярна книжнина за възрожАенското културно-историческо наслелство на старата престолнина, цялостно, систематично и полробно изследване по темата все още не е направено. Това е и целта на настоящата разработка - $\Delta$ а прослели, класифиццира и обобщи проучванията, в които се анализират ценности от културния оронА на Търново или засягат проблеми, свързани с неговото развитие, в рамките на историографоски очерк, предоставящ опорни точки на бъдещата Аисертация относно „ВъзрожАенското културно-историческо наслеАство на Велико Търново".

Макар конкретна периодизация на българската историопис, свързана с Бьлгарското Възражлане, да е известна в научната ^итература - полнесена изключително полробно от профр. Вера Бонева на база еволюционното развитие на съвременната хуманитаристика, с водещите изследователи, с институционалната срела, публикаторска база, постижения и прочие, подобни изследвания с регионален характер и с насоченост към културно-историческите ценности са в повечето случаи спорадични извън чисто историческото проследяване на групи процеси и последователности. Счита се, че за XVIII-XIX в. миналото е предалено чрез текста на изворите в "чист" виА, без изопачаване на истината и деформации, порали позиция, интерес или Аруг виА причина, а критиката е насочена основно кьм Аоказване автентичността на източника, неговата Аревност и близост Ао описаното време и събитие. Кьм края на XIX-чак АО 70-те години на XX в. водеща става позитивистката метолология на учените-изследователи, осъществявана чрез външна и вътрешна критика. В. Бонева откроява три периола: пьрви - $о$ края на 90те години на XIX век, втори - от началото $А$ среАата на XX век, трети втората половина на XX век (Boneva, 2003). Тук бихме могли $А$ Аобавим и еАин слеАващ - четвьрти периол - който обхваща Анешния XXI век, т. к. историческата наука няма стационарен характер и продьлжава своето граливно развитие, полпомагано в значителна степен от Аигитализационните процеси на този век и електронната среда с неизчерпаем ресурс и интернационален зарял. 
Възможностите за обмен на инорормация позволяват все по-точен сравнителен анализ и всеобхватност на направените научни заключения относно културни, образователни, религиозни и Аруги постижения на общности със схолНи черти на развитие и поставени цели в определен периоА от своето консолиАиране.

Ако трябва да типологизираме и разграничим отАелни групи исторически извори, в обсега на които попадат възрожАенски културноисторически ценности от Търново, то при^ожимост имат разАични критерии. От Аингвистична глеАна точка те биват свеАения на български език (писма, офрициална Аокументация, Аични архиви, книжнина и пр.), на гръцки (например конАиките на Търновската митрополия, теотерите на учимищата, на гралската община, Ар.), турски език (османотурската Аокументация на офрициалната власт), руски език (например изследванията на Юрий Венелин, Ар.), както и на много от европейските езици (пьтеписи и Аокументи, оставени от чужАи пьтешественици и мица, пребивавали във врьзка с изпьлнение на служебни зальлжения и пр.). Отчитайки насоката на изслеАванията спореА същността на обектите и техните характерни черти, то те могат $\Delta$ а се обособят като етнографрски, художествени, краеведски, с поглеА към архитектурните специорики и благоустрояването, към просветата и самите образователни институции, към цьрквата, книжнината, икономическото развитие, тьрговските

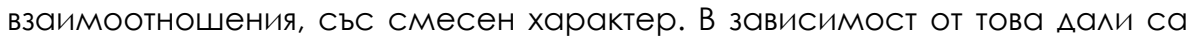
резултат от ИнАивиАуален поАХоА или са п^оА на съвместни усилия може $\Delta \mathrm{a}$ се говори за самостоятелни научни трудове и разработки, монографии, студии, статии, АокАаАи, и за сборници, АеАо на екипи от специалисти, каталози, периодични изАания, публикации от съвместно проведени проучвания и прочие. Според обхвата им биват обзорни и с конкретна тематика.

ЕАИн от първите пьтеводители, преАоставящ поАробни Аанни за Велико Търново и неговото материално и нематериално, Авижимо и неАвижимо културно наслеАство, е този от 1907 г., Аопьлващ познатия като „Упътване за В. Търново и околността му” от 1893 г., съставен от Хр. Константинов по повод проведеното IV-то Велико народно събрание от 317.05.1893 г. 
ИзАаленият от Великотърновското туристическо Аружество Трапезица "Пьтеводител на В. Търново и околността му" бива отпечатан в печатницата на Х. Т. С. Фъртунов - „с при^ожение на 30 художествено изработени образи и 1 карта на Великотьрновския окрьг", по инициатива на арх. Георги Козарев в качеството му на негов председател и с помощта на петчленна комисия. Пьтеводителят обрьща поглеА и „назаА" - в предосвобожАенския периол, с Аетайли по отношение на брой и виА на училищата, цьркви, манастири, периодични изАания и книги, събития от опустошителен характер като пожарите от 1818, 1825, 1845, 1847, 1849 г., наводнението от прелялата река Янтра от 1858 г. (Markov, 1907, pp. 7-9), Ар. И $А$ Анес той се оказва еАин от най-пьлноценните извори на историческа инорормация. Текстьт е написан от Недялко Марков. Това се случва с усилията и незаменимата помощ на Моско Москов (1862-1947 г.), чието име свързваме и с пьрвите научно публикувани материали във връзка с „черковната борба" (Moskov, 1915), с „миналото и бълещето на Велико Търново в икономическо отношение" (Moskov, 1910), с найАревното минало на Търново (Moskov, 1918). С негова полкрепа е възобновена Аейността на археологическото Аружество (основано на 18.03.1879 г. - пьрвото в България) през 1884 г. и прелможена илея за съставяне на еАин пьлен и уреден музей в Търново с основна залача „Аа издирва българската старина, исторически паметници, като налписи, стари крепости, монети, черкови и пр., които биха хвърлили по-голяма светлина на родната ни история". Той сътрудничи на периодичния печат, пише поеми, Арами, разкази и Аруги, много от които на рололюбива тематика (Aleksiev, 1972, р. 6-7).

С името на ЙорАан Кулелиев - учител, вилен общественик и краевеА, се свързва изааването на вестниците „НаАежАа" и „Общински вестник” които със запазените си в Регионална библиотека - Велико Търново броеве, предоставя огромен брой сведения за решения, взети по отношение на културните ценности от предосвобожденския периол, за организирани събития и инициативи, отличаващи се с патриотичност и ентусиазьм, характерен за времето. Неговата книга "История на цьрквата „Св. цар Борис" (бивша „Св. Константин и Елена”), написването на която му е възложена от самото цьрковно настоятелство на заседание 
от 15 май 1939 г., е своеобразно проучване на историческия й пьт Ао този момент, като за постигане на целта са му предоставени всички протоколни книги, водени от бившите настоятелства, запазената кондика при цьрквата от 1872 г., летописната книга и еАин Аневник. Самият Търновски митрополит Г. Г. Софрроний олобрява и благославя отпечатването й - като повод за 70-голишнината от построяването на цьрквата (Kuleliev, 1942). ПреглеА на документите за събирателската и творческата му Аейност, съхранени в Аьржавен архив Велико Търново, публикува Ивалин Цветков в Известията на РИМ-В. Търново през 2005 г.

Търновецьт Аеон Филипов остава в историческата ни памет с многобройните макети на сгради от XIX и XX век, изработени от гипс с впечатляваща, макар и не базирана на специализирано образование, прецизност и умение, които и Ао Анес преАстав^яват почти еАинственото визуално и материално доказателство за съществуването на тези културни ценности. Той е също така Аьлгогодишен член на ръководството на туристическо дружество "Трапезица" и полпомага арх. Козарев и екипа по изработването на считания за прьв туристически пьтеволитеА на България от 1907 г. Полага грижи за опазване и съхраняване на архитектурните и исторически обекти в Търново като преАварително ги изучава и заснема в многобройни чертежи и рисунки, преди $А$ ги превърне в макети. По негова инициатива през 1909 година се прави списьк на археологическите, архитектурни и исторически паметници в Търново с цел $а$ бьлат реставрирани и запазени. Обобщаващо изслеАване с полробни Аетайли относно макетите на $А$. Фи^ипов, част от които са представени в експозицията на музей "Възраждане и Учредително събрание" във Велико Търново, правят Т. Кънчева И Св. Атанасова (Kancheva, Atanasova, 2007). За него пишат още Т. Минчева, Николов, Я. Николова, Ж. Арагомиров, А. Кафезчиев.

Родната къща на П. Р. САавейков - роденият в Търново през 1827 г. поет, писател и учител, виден възрожленец с активна роля в борбата за независима българска цьрква и изработването на тьрновската конституция, еАин от съзАателите на новобългарския Книжовен език, журналист и общественик, Анес е музей, част от възрожленските обекти пол егидата на Регионален исторически музей - Велико Търново. 
Аичният му архив вече е официално публикуван от профо. В. Бонева през настоящата 2020 г. ИАвайки в грала още през 1856 г. А-р Васи^ х. Стоянов Берон започва внимателно да изучава културно-историческото наследство на Търново и с голямо усърАие, както твърАят всички исторически сведения, Аа събира и съхранява материали за бъдещи проучвания. Като свилетел и пряк участник в процесите в българското общество през втората половина на XIX в. (в ролята му на лекар, управител на гралските училища, касиер на Търновската община, покъсно председател на Окръжния съвет, депутат, пръв предселател на Археологическото дружество, Аиректор на гимназия „Св. Кирил"), той успява $а$ и изале книгата си „Археологически и исторически изследвания" в три Аяла през 1886 г. И тя за Аьльг периол $а$ б бъле определяна като пръв и елинствен опит за написване на история на Велико Търново (Beron, 1886).

Част от запазените в Аьржавните архиви Аични фоонАове или отАеАни архивни еАиници, чийто произхол се свързва с имената на бележити възрожленци от Търново, сами по себе си представляват също културна ценност, оставена в наслелство за поколенията. Като примери в това отношение могат $\Delta$ a ce посочат тези на $\Delta$-р Марко Павлов, Никола 3^атев, митрополит Климент, А-р Евстати Антонов, А-р Стедран Пенчев, Аимитьр Павли Иванов, Тодор Шишков, А-р Васил х. Ст. Берон, Киро Тулешков и много Аруги (Beykova and Popivanova, 1988: pp. 256-292).

"Няколко Аена разхолка по българските места" (пьтуване през 1865-1866 г.) - Иван Богоров успява да изАале в Букурещ през 1868 г. в печатницата на К. Н. Ралулеску. В книжното тяло от 58 страници е отлелено специално внимание и на Търново - споменават се "предимно дьрвените къщи без основи и почти никакви Аворове", чаршията, "архитектиката", женските и мъжките училища и образованието (Bogorov, 1868).

ЕАин от чужАенците, оставили трайни следи с трудовете си, порали което не би могъл $а$ б бьле пропуснат в настоящия очерк, е Феликс Каниц, който още през 1868 г. предприема проучване на българските земи - полкрепен от Виенската акалемия за полпомагане. Неговата "Аунавска Бьлгария и Балканът" указва 3200 селища, 35 манастира и крепости и дори бива използвана от руското командване по време на 
Руско-турската война от 1877-1878 г. (Kanitz, 1995). Многократно преиздавана слеА 1868 г, и Ао Анес. Чешкият учен Константин Иречек и неговите "История на българите”, отпечатана в Търново през 1886 г. и "Пьтувания по Бьлгария 1854-1918", са незаменим източник на сведения за тогавашното сьстояние на грала, за динамичните събития, за благосьстоянието, нагласите на търновските жители, изслеАвания с висока стойност и в съвременен аспект (Irechek, 1886), (Irechek, 1974). "Историята" - неговият Аисертационен труд, публикуван на редица чужАи езици, е изслеАване, което продьлжава $А$ се сопьлва от своя автор $А О$ самата му кончина. Всъщност това не е пьрвото му проучване на научна основа, свързано с Бьлгария, а „Книгопис на новобьлгарската книжнина - 1806-1870" с офрициална Аата 1872 г.

Първата половина на XX в. - периол, познат ни с процесите на институционализирането на науката и културата в новосфоормираната българска Аьржава, в научно обрьщение влизат монографиични изслеАвания и трудове С научна стойност, които стоят в основата на всяка изслеАователска насока от глеАна точка и на съвременното развитие на науката. Такива са "Архив на Възраждането" от Аимитьр Страшимиров, изАаден в том 1 още през 1908 г., „ЗапаАноевропейското и Българското възражАане" от 1928 г., студията "УвоА в историята на Българското възражлане", отпечатана посмьртно през 1930 г. в преАставителния сборник "1000 голини Бьлгария" на Иван Шишманов, "Ранно възраждане 1700-1860” (1939 г.) и „Фактори на българското ВъзражАане 1600-1830” на Христо Гандев от 1943 г., съзАалената от Михаил Арнаудов поредица от монографиии за водещи възрожленци - Георги С. Раковски (1922 г.), Неофит Хилендарски-Бозвели (1930г.), Иван Селимински (1931г.), екзарх Йосиф І Български (1940г.), епископ Иларион Макариополски (1925 г.), епископ Софрроний Врачански (1938 г.), Аруги.

Освен изброените Аотук изследователи, представители на пьрвия и втория периол в развитието на възрожленската историографрия като цяло и в частност по отношение на Търново, към културно-историческото наследство на грала са насочени и интересите на научните сьтрудници от екипа на първоначално познатия като Окръжен музей - Велико Търново, а Анес Регионален исторически музей. 
Тодор Николов ролята му на прьв рьководител на новосорормирания музей оставя освен спомен за огромната си отАаленост на илеята за съхраняване на старините от Търново, и елно съвместно с Аимитър Цончев изАание - „Волач за старините в граА Велико Търново и околността му" от 1933 г.

Третият периол от глеАна точка на историографрската к^асификация на продр. Бонева е богат на публикации относно Възрожденското наследство, белязан с опити за критичен анализ в научните поАХоАи, но вьпреки това в обстановка на политическа конюнктура - от изслеАователи с висока степен на прилобито образование в България и в чужлестранни университети. СъзАават се обзорни изследвания с все по-голям обхват като например „Бьлгарският граА” и „Българската къща" през епохата на Възраждането - и двете изследвания на Тодор Златев от 1955 г., "Изкуството на Българското ВъзражАане" на Никола Мавродинов от 1957 г., Маню Стоянов - „Българската възрожленската книжнина. Аналитичен репертоар на българските книги и периодични издания 1806-1878. Т. І. - от 1957 г., „Интересьт кьм българските писмени паметници през епохата на Вьзраждането" от Маргарита Кузманова - 1964 г., Асен Василиев с "Българските възрожленски майстори: живописци, резбари, строители" от 1966г., Николай ТоАоров, с „Балканският граА през XV- XIX в. Социалноикономическо и мемоградрско развитие." От 1975 г., Никола Генчев с „Българската култура XV-XIX в.” - 1988 г., „История на Велико Търново: в 3 тома (том 2 - относно периола на ВъзражАане) - от екип: Аимитьр Страшимиров, Наля Аанова, др. - от 1986 г., Петко Ст. Петков и Вера Бонева - „Бьлгарите преА Европа през 1869 година" - от 1993 г., "Пьтеводител в проблематиката и митературата по история на българското възраждане", Николай Проданов с „Материали по българска историография. Част 1. ВъзрожАенска историопис", 1993 г. и част 2 от 1996 г., „Цьрковно-националното Авижение през епохата на Вьзраждането в българската мемоаристика" - 1999 г. на Вера Бонева, Иван Стоянов - „История на Бьлгарското Възраждане” от 1999 г., като това изброяване би могло да продьлжи в още много позиции, поради значителните приноси към научното познание за "преходьт към новото време". 
Но връщайки се към Търново и проследяването на историографоските източници относно неговото културно-историческо наслелство, ще обърнем специално внимание на онези учени, чиито научни търсения в по-голяма или по-малка степен, а някои изцяло, са обвързани с възрожленските носители на памет.

Иван Снегаров (1883-1971г.), познат в научните среди като автор на многобройни исторически съчинения и профессор по цьрковна история, обръща своя поглеА към ценности от възрожленския периол на Търново. Очеркът му върху историята на Търновската митрополия, сьпроволен с публикуване на стари цьрковни конАики, се отличава с извьршен от самия автор превод от грьцки език и негови Аични коментари и анализи в Аопьлнение. Подборьт му на 14 пьтешественици, среА които най-много са учени археолози, слависти, географои, със споделените им впечатления от различни страни на живота на българина, е в основата на неговата книга със заглавие „Българските земи през погледа на чужлите пьтешественици 1828-1853". Опорните точки, по които се стреми Аа се прильржа в своето изложение с оглеА максимална близост Ао реалното положение на "целокупния български нарол" през Възраждането, са градоустройство, обществена хигиена, стопански и културен живот, просвета, икономическа и политическа гнет от турската управляваща к^aca и пр. (Snegarov, Nikolov, 1997).

„Възрожленецьт Стефран Пенев Ахтар" - изследване в научно обрьщение от 1985 г, както и „Засилване на интереса на българското възрожАенско общество към родните старини (30-те - 50-те гоАини на XIX в.)" - от 1994 г., на профо. Огняна Маждракова-Чавдарова, са само една малка част от приносьт й към историческото познаване на ВъзрожАенския периол.

Профр. Наля Аанова разглежАа историята на Търновската гралска община и периола на ранното Възражлане в свои публикации. ИзслеАвайки тефртерьт на Търновската община и отбелязвайки факта, че Аотогава не са изпо^звани пьАноценно всички АОмашни извори на гръцки език, тя прави опит $\Delta а$ характеризира цьрковно-просветния живот на грала и да представи същността и функциите на общината в края на XVIII в. (Danova, 1980), (Danova, 2000). 
Отново с изслелване на гралската община в Тьрново, но през XIX век, се свързва името на Тодорка Араганова, която от позицията си на Аьлгогодишен уредник и научен сьтрудник в отАел „ВъзражАане и национално-освободителни борби" на Исторически музей - Велико Търново, Аопринася за изясняване на ролята й в разрешаване на проблеми от социален, трудов, битов, културен и просветителски характер (Draganova, 1966). Историческото ни наследство е в основата на нейните публикации - 15 студии и наА 200 научни и популярни статии с акцент върху граАоустройствения облик - еАно изКАючително Аетайлно изслелване на гралската срела на възрожленско Търново (Draganova, 1972), върху развитието на музейното Аело, възрожленският периоличен печат, читалищната Аейност, просветното и културно развитие - познати от гоАините 1982, 1993, 1995, относно бележити представители на обществото, Аруги. Съвместно с Цветана Генчева и Ралка Цонева публикуват своя труа - „Хроника на Търновския край през ВъзражАането” през 1994 г., който е с приносен характер по отношение на обектите от Търново и околността, а малко по-рано - през 1989 г., заеАно със Снежана Попова и Йордан Тодоров - „Велико Търново - пьтеводител”.

Н. С. Тянка Минчева в продьлжение на 35 години от профресионалния си пьт като част от екипа на Регионален исторически музей - Велико Търново изслеАва и публикува резултатите от своите научни търсения във врьзка с богатото историческо минало на Велико Търново и околностите му в цялата му многоаспектност - културно-просветен и политически живот, цьрковни и революционни борби за освобожАение, Авижими и неАвижими културни ценности от ВъзражАането, приноси на бележити мичности, социални и икономически аспекти от битието на възрожленския българин, музейно Аело и много Аруги. В книгата й „ГраА Велико Търново и околностите му в историческата памет" авторката е събрала само част от Аесетките научни и научно-популярни статии, публикувани през голините в различни сборници, известия, гоАишници, периолични изАания и пр. (Mincheva, 2013) Предстоящо е изАаването на втора част от споменатия труд. Пенка Ибришимова още през 1966 г. публикува свое изслеАване във връзка с "историята на училищата във Великотърновски окрьг през Вьзраждането" (Ibrishimova, 1966). 
В съавторство с Тодорка Араганова съзАават „Паметници на признателност (Каталог на паметниците от 1877-1878 г. във Великотърновски окрьг" през 1977 г. И „Ролната къща на Петко Р. Славейков" през 1979 г.

В своята статия - „Велико Търново в полезрението на пьтеписната ^итература през XVI-XIX век" историкьт Павлина В^алева прослеАява научното изследване на пьтеписите в бьлгарската историографрия и мястото на старопрестолния ТърновграА в тях, наченато още от известният чешки изследовател Константин Иречек в пьтеписите му „Пьтувания по България". На основата на пьтеписите на наши и чужАи пьтешественици, тя публикува още няколко изслеАвания - на Търновската архитектура през Възраждането, на душевността и моральт на търновци през XX век, на архитектурните шедьоври на майстор Никола Фичев (Vladeva, 1997), (Vladeva, 2000-2001).

И ако продьлжим следването на периодизацията в развитието на вьзрожАенската историопис, то правилно би било да не пропускаме и сравнително „новите" изслеАователски търсения и публикувани резултати от тях - от началото на XXI век Ао Анес (20 голини) - периол, белязан в изключителна степен от процеса на Аигитализация и г^обализация. Значима част от авторите предлагат своите трудове в електронна среда, С напьлно Свободен или С ограничен по някакъв критерий Аостьп, приАружени от всички Аопьлнителни приложения и фрактологични Аоказателства.

Продр. Петко Ст. Петков, освен като автор на множество научни трудове за църковно-националните борби през периола на Българското възражлане, за процесите на утвържлаване на българската дьржава, за много конкретни исторически събития и отАелни бележити мичности, обрьща своя поглеА и към националното богатство, което Търново предоставя и съхранява, предлага илеи за културно-исторически маршрути. В продьлжение на 6 голини, от 2014 г., организираната с негово активно участие, сьвместно с Института по математика и инорорматика при Българска акалемия на науките, Великотьрновския университет и Регионалния акалемичен центьр, конфееренция на тема „Културно-историческо наследство: Опазване, представяне, 
Аигитализация" предлага научните тьрсения на специалисти от различни сорери, съвместни проекти, новите възможности на съвременните технологии, предложения за бьлещо развитие по отношение на културния туризъм, като всички публикации са и електронно Аостъпни. Изследванията му на архитектурното творчество на Уста Колю Фичето във Велико Търново и околността преАоставят комп^ексен поАхоА КъМ строителния гений на майстора-строител, остави^ в наслеАство значим брой обекти с религиозен и светски характер (Petkov, 2015), (Petkov 2016).

Аруг представител на РИМ - Велико Търново, по настоящем главен уредник, е Тодорка Недева, която отлава също необходимото внимание на архитектурните шеАьоври, останали в наслеАство от известният строител, както и на приносите на арх. Теофил Теофииов и Моско Москов за запазването на историческото наслеАство и цялостното развитие на Велико Търново.

За живота и творчеството на пьрвомайстор Никола Фичев в научно обрьщение са многобройни публикации, част от които от строго архитектурна позиция на профресионалистите в тази област - като архитект Георги Козарев с негови изслеАвания, излезли от печат през 1933 г. („Трима майстори - три великана, три мъченика на българското строителство и стопанство-Уста Колю Фичето, Аобри Желязков ФабрикъАЖи и Уста Тодор Карахристоолу") и през 1953 г.в колектив (Майстор Никола Фичев (Уста Колю Фичето) 1800-1881"), арх. Маргарита Коева - с изследвания, свързани с годините 1976 („ВъзрожАенските цьркви от Източна и Сренна Стара планина" в Материали за Българското възражлане), 1980 („Архитектониката на възрожленските иконостаси” в Проблеми на изкуството), 1989 („Типология на архитектурното развитие през Възражлането" в Българската нация през Възражлането) и др., арх. Маргарита Харбова - с годината 1991 („Градоустройство и архитектура по българските земи през XV-XVIII в.”) и 1998 г. („Средновековната и възрожленската култова архитектура на Търново-XIII -XIX в." в Известията на РИМ-В. Търново), арх. Теофри^ Теофилов - с „Къщата с маймунката в своята сто и петлесет годишна история" от 2001 г. - в Известията на РИМВ.Търново, арх. Николай Тулешков - с „Български строителни центрове 
XV-XIX в.” от 1987 г. (в списание „Векове”), и „Пьрвомайстор Никола Фичев - живот и творчество (1800-1881) - от участие в конореренция, посветена на 200-годишнината от рождението на Пьрвомайстора, както и „Архитектурата на старите българи” - от 2001 г., арх. РаАосвета Кирова - с елно изследване, публикувано в специализираното списание "Паметници, реставрация, музеи" - относно цьрквата "Св. Спас" и съвременното й сьстояние, включващо и предложение за консервация, реставрация и алаптация с музейна функция - от 2010 г. Освен отАелни публикации относно конкретен обект, резултат от Аейността на Никола Фичев, в годините биват издавани и обзорни трудове с акцент върху възрожАенските ни православни храмове от Търново. ВслеАствие на екипна работа на учени и изследователи от печат излизат - „История на цьрквата "Св. Константин и Елена" - пол редакцията на акаА. Иван Ралев, „Храмьт „Успение Богородично” Велико Търново” от А. ВелковаГайдарджиева и Ел. Попова, „История на кателралния храм Рожлество пресветия Богородици Велико Търново” от Е. Налбантова, „Храмьт Св. Николай - Велико Търново" от Ив. Радев и колектив, Ар. В Аопьлнение е необходимо $А$ с се споменат и проучватели с интерес вьрху Аруги обекти извьн цьрковните, макар и те $а$ а са с преобладаващ дял - Тянка Минчева изследва музея „Затвор" и музея „ВъзражАане и Учредително събрание”, Стефран Бейков и Светла Атанасова - музея „Възраждане и Учредително събрание, Живка Ралева и Катя Митова-Ганева - Самоводската чаршия. В обобщаващи издания като например „Архитектурата на Българското възраждане" се засягат много от характерните и регионални особености при архитектурните решения за изграждане на цьркви, училища, ханове, чешми, мостове, къщи, гражАански постройки. Като част от проект, подкрепен от представителите на научните институции във В. Търново Института по математика и инфоорматика-БАН, Великотьрновски университет и Регионален исторически музей, както и общината, за "ця^остна цифрровизация на творчеството на възрожАенския архитект "Майсторьт и времето", в рамките на пьрвото изАание на конореренцията „Културно-историческо наслеАство: опазване, представяне, Аигитализация,, през 2014 г. бива представена мобилната изложба „Разрушение и съзилание". 
Посвещава се на 150-годишнината от построяването на цьрквата "Св. Спас" и на 100-годишнината от разрушителното земетресение" (Kancheva, 2015: р.100). Научният екип полага началото и на следваща инициатива - за "сьзАаване на Виртуален музей на архитектурното наследство на Колю Фичето с галерии, включващи и 3D експозиция от избрани колекции на 3D цифррови обекти, а също туристически видеогайА с мултилингвистичен характер (Bogdanova, 2015, рр. 21-22). Арх. Аонка Колева, като отговорен представител на община Велико Търново, в годините полпомага изработването на редица проекти, базирани на културно-историческите ценности от ВъзрожАенския граА, тяхното съхранение в максимално автентичен виА и поАХОАящото им презентиране. Освен Аьлгогодишните й усилия и труа в посока поАХодящото им интегриране в съвременната градска коноригурация, тя насочва научните си интереси и в посока изследване на архитектурата с културна и обществена стойност по отношение на читалище „НадежАа" (Koleva, 2019).

Самата 140-годишна история на читалище „НалежАа 1869" е обект на научни търсения през различните периоли от своето съществуване, започнало с учредяването му в общата стая при цьрквата "Св. Никола" гоАини преАи ОсвобожАението. ПослеАната изАалена книга от 2019 г. сьс заглавие „История на читалище „НалежАа 1869" Велико Търново е резултат от съвместната дейност на н. с. Кинка Панайотова и н. с. Невяна Бъчварова. Интересьт на Невяна Бъчварова към културните институции от ВъзражАането проличава още в нейно изследване от 1993 г. относно Аьржавната културна политика и проблеми на музея при читалище „Належла" във Велико Тьрново. Кинка Панайотова от своя страна насочва своето внимание предимно към стопанската структура на града и устойчивото му икономическо развитие през вековете, но е позната и еАна нейна публикация за неизвестен летопис вьрху стара Аьрвена врата в Асенова махала (1822-1924) от 1994 г. (Известия на РИМ-В. Търново). Името на акал. Иван Ралев е емблематично що се отнася до митературата и историята на Българското възражАане. Като фииолог и историк С изКлючителен принос в научните изслеАвания, с Аетайлни и прецизни анализи на книжовното ни богатство и периодите му на 
развитие („Бьлгарска възрожленска литература" - научно изследване от 1980 г. И „Бьлгарската вьзрожАенска Аитература Ао 40-те голини на XIX в. от 1982 г.), той всеобхватно се ангажира с тематиката, изАавайки и публикувайки на тьрновска земя своите "погребани книги на Възражлането” през 1994 г., „История на Велико Търново XVIII-XIX в.” в съавторство (през 2000 г.), „Храмът Св. Николай” (2003 г.), „История и култура на България в дати. Възраждане." (1997 г.), както и редица Аруги.

Освен като част от екипа, с който работи акал. Иван Ралев, Елена Налбантова - също български митературен историк, публикува самостоятелно „Моето чиракуване в живота" на Киро Тулешков през 1997 г., "История на катедралния храм Рождество пресветия Богородици" през 2009 г., множество енциклопедии, биографрии и атласи на български възрожАенски автори.

C^ел 2000 г. н. с. Катя Митова-Ганева - представител на екипа на Музея в грал Велико Търново, преллага на вниманието ни „Велико Търново-непознато, Аюбопитно и обичано” (2008г.) и „Споменъ $3 а$ Търново. Страници от следосвобожленската история на грала" от 2009 г. - в които част от събраните от авторката материали са на основание културно-исторически ценности от ВъзражАането на Търново и процесите на развитие, заенно с постиженията на представителите на търновското общество.

В няколко пореАни гоАини Н. С. НаАка Василева, под научното ръководство на Кинка Панайотова, издава поредица от свои етнографрски проучвания на Велико Търново, където търси историческите корени на търновската градска култура, бит и Аушевност - през 2010 г. „Посрещането на гости по стар тьрновски обичай”, 2013 г. - „Аомьт”, а през 2014 г. - „Бит и Аушевност”. Архитектурата на големите търновски къщи е разгледана в етнографрска проекция, заеАно с богат снимков (в преобладаващата си част цветен и в много Аобра резолюция), както и архивен, материал.

Макар и индиректно, някои сведения относно обекти от възрожленското културно-историческо наслелство на Велико Търново, могат $\Delta$ а бълат почерпени от редица изслеАвания с Аруг фоокус и $А$ ата на публикуване през последните Аве десетилетия - примери в това 
отношение са: Симеон Недков с неговите „Музеи и музеология” (от 1998 г.), „История на музейното дело в България" (като онлайн ресурс), Вера Бонева - „Музеи и туризьм в Бьлгария (2011г.), „Музейната мрежа в България" (2014 г.), " Мемориалните музеи и експозиции в културната инораструктура на съвременна България" (2019г.), „Корпус на стенописите в България от XVIII в." от Иванка Гергова и Ар. (от 2006 г.) и ", Корпус на стенописите от пьрвата половина на XIX в. в България" от колектив (2018 г.), Иван ТютюнАжиев - с „Търновската митрополия XV-XIX в." (от 2007 г.), „Търновският епископат XII-XXI в.” (от 2008 г.), ВАаАимир В^аАов - с „ЕАинското училище в Търново и православният клир през пьрвата половина на XIX в." и „Тьрновската община и елинското образование в края на XVIII И пьрвата половина на XIX век." (от 2007 г.), Жана Пенчева „ВъзрожАенските православни храмове" (от 2015 г.), Пламен Събев със "Страстите Христови: икони и стенописи XVIII-XIX в., Великотърновска епархия” (от 2017 г.), Светла Атанасова - с „ВъзрожАенски печати от фронда на РИМ-В. Търново” - 2008 г. и "Търновските търговски Аружества през ВъзражАането” (2014 г.), Петко Ст. Петков - с „Нова история на България XVIIIXIX век. Аокументи. Бележки. Карти." (от 2020 г.), Евгени Сачев - и неговото „Културно наследство и национална сигурност” (2005 г.), Щелиян Щерионов - със своя труа „Аемографоско развитие на българските земи през Възраждането” (2012 г.), Соня Аиексиева - „Културният туризъм - мисията на Велико Търново” (2011г.), Софиия Василева - „Културно наследство и устойчиво развитие. Концепции, политики, Аобри практики" (2013г.) и "Аьржавна политика за културно-историческото наследство на България 1878-2009" - резултат от съвместната й работа със Стоян Аенчев (2010 г.), Тодор Крьстев, „Историческите територии: интеграционно поле за култура и туризъм" (от 2009 г.), и Аруги.

ЕАин интересен проект, реализиран и публикуван през 2015 г., за културно-историческата памет и нейната проекция в м^алото поколение чрез различен интерАисциплинарен подхоА, част от иновативното обучение в образователната ни система, е този на Виолета Стойчева и Кина Котларска - „Велико Търново- музей пол открито небе. Пелагогически гил.". 
Врьзката межАу същността и функциите на наслеАството с паметта и фрормирането на илентичности е изяснена внимателно и Аетай^но като се Аостига и Ао практико-приложна част по отношение отАелните елементи на културно- историческото наслелство. Проектьт е своеобразен мост межАу поколенията, местата и ценностите, носители на памет, част от които са именно от периола на Възраждането, и $А$ ава насоки за бьлеща технология на работа с наследството (Stoycheva, Kotlarska, 2015).

В заключение е необхолимо да отбележим, че елин историографрски очерк не остава „заключен” в прогреса на времето, а е с "отворено” сьдьржание за следващи изслеАователски тьрсения, проучвания, анализи, посреАством методологичен инструментариум с традиционен или интерАисциплинарен характер.

Велико Търново е граА с „историческа територия", където културните механизми имат всички налични преАпоставки $А$ За завижат голямото колело на устойчиво му развитие. Туризьм и култура, образование и национално самочувствие - обвързаности, които съхранените културноисторическите ценности пьлноценно полкрепят, са неговото основание Аа бъле с ранга на Ауховна столица на България.

Възрожленското наслеАство носи отпечатька на времето с най-бурно развитие и прогрес вьв всяко отношение и макар голяма част от него $\Delta \mathrm{a}$ e безвьзвратно погубено в пожари, наводнения, борбите за национално освобожАение и при Аруги обстоятелства, Аостигналите $о$ нас ценности за безпрекословна и точна изява и Аоказателство за високата Аеятелност на преАставителите на българското възрожленско общество. 


\section{АИTEPATYPA / REFERENCES}

Aleksiev, Jordan (1972). More about the history of Archaeological society in Veliko Tarnovo. - Proceedings of the Regional museum of history-V. Tarnovo, book 5. V. Tarnovo, 1972, pp. 5-19. ISSN 0861-5888 (In Bulgarian) [Амексиев, ЙорАан. Още за историята на археологическото Аружество вьв Велико Търново. - Известия на Окрьжния исторически музей- В. Търново, Кн. 5. В. Търново, 1972, с. 5-19 ISSN 0861-5888].

Beron, Vasil (1886). Archaeological and historical studies. Publisher: P. H. Panayotov, Tarnovo, Bulgaria, 1886. (In Bulgarian) [Берон, Васи^. Археологически и исторически изследвания. Тьрново: Печатница на П. Х. Панайотов, 1886].

Beykova, Tsvetka and Pavlina Popivanova (1988). Guide to archive funds 1492-1944. Complied by: Beykova, Tsvetka and Pavlina Popivanova. V. Tarnovo, State archive, 1988 (In Bulgarian) [Пьтеводител на архивните фоннове 1492-1944. Съст.: Бейкова, Цветка, Павлина Попиванова. В. Търново, Аьржавен архив, 1988]

Beykova, Tsvetka; Anushka Sabeva et al. (2013). Guide to funds of State archive-Veliko Tarnovo 1944-2012. Complied by: Beykova, Tsvetka, Anushka Sabeva, others. Veliko Tarnovo, State archive, 2013. (In Bulgarian) [Пьтеводител по фондовете на Аьржавен архив-Велико Търново 1944-2012. Съст.: Бейкова, Цветка, Анушка Събева, Ар. Велико Търново, Аьржавен архив, 2013].

Bogdanova, Galina (2015). Interdisciplinary aspects in the studies for preservation, presentation and digitalization of cultural, historical and scientific heritage in the region of Veliko Tarnovo. - In: Cultural and historical heritage: preservation, presentation, digitalization, Vol. 1, 26-27.11.2014. V. Tarnovo, Reg. library "P.R. Slaveykov", 2015, pp. 14-28. <http://www.math.bas.bg/vt/kin/book-1/02-KIN-2014-1.pdf >. ISSN 2367-8038 (In Bulgarian) [БогАанова, Галина. ИнтерАисциплинарни аспекти при изслеАванията за запазване, представяне и Аигитализация на културноисторическото и научно наследство в региона на Велико Търново. - В: Културно-историческо наслеАство: опазване, представяне, Аигитализация. Т. 1, 26-27.11.2014. В. Търново, Народна библиотека „П. Р. САавейков", 2015, с. 14-28. <http://www.math.bas.bg/vt/kin/book-1/02KIN-2014-1.pdf > ISSN 2367-8038] 
Bogorov, Ivan (1868). A few days walk around the Bulgarian places. Bucharest, Ed. K. N. Radulescu, 1868. (In Bulgarian) [Богоров, Иван. Няколко дена разхолка по българските места. Букурещ, Печатница Ha K. Н. РaАy^еску, 1868 г.]

Boneva, Vera (2003). The Bulgarian Revival in Bulgarian historiography. Electronic magazine LiterNet, 04.03.2003, No. 3 (41) <http:// https://liternet.bg/publish8/vboneva/istoriopis.htm> (01.12.2020; 17:51). (In Bulgarian) [Бонева, Вера. Българското възражлане в българската историопис. - Електронно списание LiterNet, 04.03.2003, No. 3 (41) <http:// https://liternet.bg/publish8/vboneva/istoriopis.htm> (01.12.2020; $17: 51)]$.

Danova, Nadya (1980). To the history of Tarnovo city community during the Revival. - Historical review, book 1, V. Tarnovo, 1980, pp.106-124. ISSN 0323-9748 (In Bulgarian) [Аанова, НаАя. Кьм историята на Търновската гралска община през Възраждането. - Исторически преглеА, бр.1. В. Търново, 1980, с. 106-124. ISSN 0323-9748 ].

Danova, Nadya (2000). Veliko Tarnovo during the early Revival (XVIII-first quarter of XIX c.). - In: History of Veliko Tarnovo. Late Middle ages, Revival, modern history (1393-1940). Part 2. V. Tarnovo, Slovo, 2000, pp. 89-92. ISBN - 954-439674-8 (In Bulgarian) [Аанова, НаАя. Велико Търново през ранното ВъзражАане (XVIII-пьрвата четвьрт на XIX в.). - В: История на Велико Търново. Кьсно средновековие, Възраждане, нова история (1393-1940). Т. 2. В. Търново, САОво, 2000, с. 89-92. ISBN - 954-439-674-8].

Draganova, Todorka (1966). City community in Tarnovo during XIX c. Proceedings of Regional museum of history-V. Tarnovo, book 3, 1966, pp. 73-96. ISSN 0861-5888 (In Bulgarian) [Араганова, ТоАорка. ГраАската община в гр. Търново през XIX в. - Известия на ОИМ-В. Търново, кн. 3, 1966, c. 73-96. ISSN 0861-5888].

Draganova, Todorka (1972). Tarnovo during XIX c. (City plan view according to documents, travel notes, memories of contemporaries and pictures). Proceedings of Regional museum of history- $\mathrm{V}$. Tarnovo, book 5, 1972, pp. 163-214. ISSN 0861-5888 (In Bulgarian) [Араганова, Тодорка. Търново през XIX век (Градоустройствен облик по Аокументи, пьтеписи, спомени на съвременници и снимки). - Известия на Исторически музей, кн. 5, 1972, с.163-214. ISSN 0861-5888]. 
Irechek, Konstantin Josif (1886). History of the Bulgarians. Tarnovo, Sc. Mag.,1886. (In Bulgarian) [Иречек, Константин Йосиф. История на българите. Търново, Науч, сп. 1886].

Irechek, Konstantin Josif (1974). Trips around Bulgaria. Sofia, Science and art, 1974. (In Bulgarian) [Иречек, Константин Йосиф. Пьтувания по България. Софиия, Наука и изкуство, 1974].

Ibrishimova, Penka (1966). To the history of schools in Veliko Tarnovo region during the Revival period. - Proceedings of the Regional museum of history-V. Tarnovo, book 3, 1966, pp. 97-109. ISSN 0861-5888 (In Bulgarian) [Ибришимова, Пенка. Кьм историята на училищата във Великотьрновски окрьг през Възраждането. - Известия на Окръжен музей-В. Търново, Кн. 3, 1966, с. 97-109. ISSN 0861-5888].

Kancheva, Stefka; Atanasova, Svetla (2007). The spirit of Tarnovo architecture from the Revival period in Leon Filipov's models. - In: Cultural and historical heritage of Troyan region, book 15. Reports of scientific meeting "The city - history, ethnology, culture", 12-13 Oct. 2006. Troyan, IFO design, 2007, pp. 206-210. (In Bulgarian) [Кьнчева, Стефока, Светла Атанасова. Аухьт на Търновската възрожленска архитектура в макетите на Аеон Филипов. - В: Културно-историческото наслеАство на Троянския край. Кн. 15. АоклаАи от Научна среща "ГраАьт история, етнология, култура", проведена на 12 и 13 октомври 2006 г. в МНХЗПИ - Троян. Троян, ИФО Аизайн, 2007, с. 206-210].

Kancheva, Stefka (2015). From the demolition to the creation (presentation of nontraditional mobile exhibition "Demolition and creation"- first stage of digitalization of the Kolyu Ficheto works). - In: Cultural and historical heritage: preservation, presentation, digitalization, Vol. 1, 26-27.11.2014. V. Tarnovo, Reg. library "P.R. Slaveykov", 2015, pp. 100-114. < http://www.math.bas.bg/vt/kin/book-1/11-KIN-2014-1.pdf>. ISSN 2367-8038] (In Bulgarian) [Кънчева, Стедкка. От разрушението към съзиланието (представяне на нетрадиционната мобилна изложба „Разрушение и сьзилание" - пьрви етап от цифрровизацията на творчеството на Колю Фичето). - В: Културно-историческо наслелство: опазване, представяне, Аигитализация. Т. 1, 26-27.11.2014. В. Търново, Нар. библиотека „П. Р. Славейков", 2015, с.100-114. < http://www.math.bas.bg/vt/kin/book-1/11KIN-2014-1.pdf>. ISSN 2367-8038] 
Kanitz, Felix (1995). Danube Bulgaria and the Balkans: historical- geographicethnographic travel studies from 1860 to 1879: Vol. 1. Sofia, Borina, 1995. ISBN - 954-500-058-9. (In Bulgarian) [Каниц, Феликс. Аунавска Бьлгария и Балканьт: историческо-географрско-етнографоски пьтеписни проучвания от 1860 Ао 1879, Т.1. Софрия, Борина, 1995. ISBN - 954-500058-9]

Koleva, Donka (2019). Architecture with cultural and public value, sealed in the 150- year-history of Tarnovo community centre "Nadezhda". - In: Cultural and historical heritage: preservation, presentation, digitalization, Vol. 5, book 1, V. Tarnovo, 2019, рр. 65-72. ISSN 2367-8038 (In Bulgarian) [Колева, Аонка Архитектура с културна и обществена стойност, запечатана в 150голишната история на тьрновското читалище „НалежАа". - В: Културноисторическо наследство-опазване, представяне, Аигитализация. Т. 5, бр. 1, В. Търново, 2019, с. 65-72. ISSN 2367-8038].

Kuleliev, Jordan (1942). History of "St. tzar Boris"church in Veliko Tarnovo. V. Tarnovo: Church board, 1942. (In Bulgarian) [Кулелиев, ЙорАан. История на църквата „Св. Цар Борис” във В. Търново. В. Търново: Цьрк.настоятелство, 1942].

Markov, Nedyalko (1907). Guide-book of Tarnovo and its surroundings. V. Tarnovo. V. Tarnovo, H. T. S. Fartunov, 1907. (In Bulgarian) [Марков, Недялко. Пьтеводител на Търново и околността му. В. Търново: Х. Т. С. Фъртунов, 1907].

Mincheva, Tyanka (2013). The city of Veliko Tarnovo and its surroundings in our historical memory. Kiev, Osnova Publishing House Ltd., 2013. ISBN 978-966699-754- 1 (In Bulgarian) [Минчева, Тянка. Грал Велико Търново и околностите му в историческата ни памет. Киев, ИзАателство „Основа" ООА, 2013. ISBN 978-966-699- 754-1].

Moskov, Mosko (1910). The past and the future of Veliko Tarnovo in economic terms. Tarnovo, 1910. (In Bulgarian) [Москов, Моско. Миналото и бълещето на Велико Търново в икономическо отношение. Търново, 1910].

Moskov, Mosko (1915). Tarnovo in the church struggle. Tarnovo, 1915. (In Bulgarian) [Москов, Моско. Търново в черковната борба. Търново, 1915].

Moskov, Mosko (1918). Tarnovo in its most ancient past. Tarnovo: Tzarevec, 1918. (In Bulgarian) [Москов, Моско. Търново в най-Аревното си минало. Търново, Ар-во Царевец, 1918]. 
Petkov, Petko St. (2015). Historical view at some works of master Kolyu Ficheto. In: Cultural and historical heritage: preservation, presentation, digitalization, Vol. 1, 26-27.1 1.2014. V. Tarnovo, Reg. library "P. R. Slaveykov", 2015, pp. 513. <http://www.math.bas.bg/vt/kin/book-1/KIN-2014-1.pdf>. ISSN 2367-8038 (In Bulgarian) [Петков, П. Ст. Исторически поглеА кьм някои обекти от творчеството на майстор Колю Фичето. - В: Културно-историческо наследство: опазване, представяне, Аигитализация. Т. 1, 26-27.11.2014. В. Търново, Нар. библиотека „П. Р. Славейков", 2015, с. 5-13. <http://www.math.bas.bg/vt/kin/book-1/KIN-2014-1.pdf>. ISSN 2367-8038]

Petkov, Petko St. (2016). Master Kolyu Ficheto - the architectural genius of the Bulgarian Revival. - In: Cultural and historical heritage: preservation, presentation, digitalization. Vol. 2, 24-25.03.2016. V. Tarnovo, Reg. library "P. R. Slaveykov". 2016, pp. 11-13. <http://www.math.bas.bg/vt/kin/book-2/KIN-2016.pdf>. ISSN 2367-8038 (In Bulgarian) [Петков, П. Ст. Уста Колю Фичето-архитектурният гений на българското Възраждане. - В: Културно-историческо наследствоопазване, прелставяне, Аигитализация. Т. 2, 24-25.03.2016, В. Търново, Рег. библиотека „П. Р. Славейков". 2016, с. 11-13. < http://www.math.bas.bg/vt/kin/book-2/KIN-2016.pdf>ISSN 2367-8038].

Pletnyov, Georgi (1985). Tarnovo as a capital of the Bulgarian state in the historical memory during the Revival period. - In: Veliko Tarnovo in the historical destiny of Bulgarian nation. V. Tarnovo, Regional council for culture, 1985, pp. 142-154. (In Bulgarian) [Плетньов, Георги. Тьрново като столица на българската Аьржава в историческата памет през Вьзражлането. В: Велико Търново в историческата съдба на българския народ. В. Търново: Окр. съвет за култура. 1985, с. 142-154.].

Snegarov, Ivan; Nikolov, Veselin (1977). The Bulgarian territories through the foreign traveller's glance 1828-1853. Sofia, Publishing house "assoc. prof. M. Drinov", 1997. ISBN 954-430-455-X (In Bulgarian) [Снегаров, Иван, Веселин Николов. Българските земи през погледа на чужАите пьтешественици 1828-1853. Софрия, АИ „профр. М. Аринов”, 1997. ISBN 954-430-455-X]. 
Stoycheva, Violeta; Kotlarska, Kina (2015). Veliko Tarnovo - museum under the open sky. Pedagogical guide. Sofia, Paradigma, 2015. ISBN 978-954326-249-6 (In Bulgarian) [Стойчева, Виолета, Кина Котларска. Велико Търново- музей пол открито небе. Педагогически гиА. Софрия, ПараАигма, 2015. ISBN 978-954-326-249-6].

Vladeva, Pavlina (1997). Tarnovo architecture during the Revival in the travel notes of our and foreign travellers. - Proceedings of Regional museum of history-V.

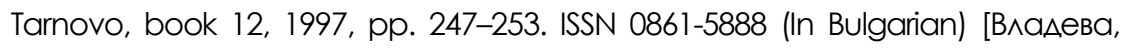
Павлина. Търновската архитектура през Възраждането в пьтеписите на наши и чужАи пьтешественици. - Известия на Исторически музей-Велико Търново, кн.12, 1997, с. 247-253. ISSN 0861-5888].

Vladeva, Pavlina (2000-2001). Felix Kanitz for the architectural masterpieces of master Nikola Fichev. - Proceedings of Regional museum of history-V. Tarnovo, book 15-16, 2000-2001. V. Tarnovo, pp. 285-303. ISSN 0861-5888 (In Bulgarian) [Влалева, Павлина Феликс Каниц за архитектурните шедьоври на майстор Никола Фичев. - Известия на РИМ-В. Тьрново, Кн.15-16. В. Търново, 2000-2001, с. 285-303. ISSN 0861-5888]. 


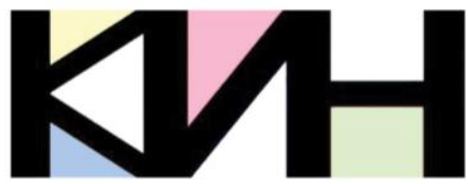

КУАТУРНО-ИСТОРИЧЕСКО НАСАЕАСТВО:

ОПАЗВАНЕ, ПРЕАСТАВЯНЕ, АИГИТААИЗАЦИЯ

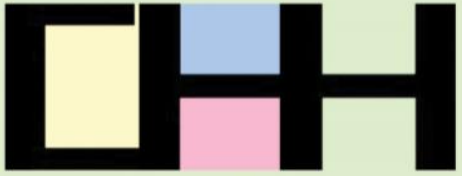

CULTURAL AND HISTORICAL HERITAGE: PRESERVATION, PRESENTATION, DIGITIZATION
Материалите в сборника са обект на авторско право. Разрешава се безвъзмезАното ползване на техни електронни/ хартиени копия само за лична употреба или обучение, при пь^но цитиране на текущата страница и слеА писмена декларация от цитиращия за мипса на търговски намерения.

(с) Авторски колектив, 2020

Техническо реАактори: Калина Сотирова-Вълкова Николай Ноев Паска^ Пиперков

\section{Editors}

Petko St. Petkov

Galina Bogdanova

This work is subject to copyright. Open and free of charge use of digital/hard copies of publications is granted only for personal or educational use, with full citation of the current page, and after written declaration of the quoting side for notcommercial Intention.

(C) Authors` Group, 2020

Technical editors:

Kalina Sotirova-Valkova

Nikolay Noev

Paskal Piperkov

НАЦИА регистрационен № 1209

Научна пореАица: том 6, брой 2 (9)/2020

Science series: vol. 6 , issue $2(9) / 2020$

NCID Registry No. 1209

www.math.bas.bg/vt/kin

ISSN: 2367-8038 